\title{
PENYELESAIAN SENGKETA PERBANKAN SYARIAH MELALUI PENGADILAN AGAMA: SUATU STUDI HUKUM NORMATIF
}

\section{SHARIA BANKING DISPUTE SETTLEMENT THROUGH RELIGOUS COURTS: A NORMATIVE LAW STUDY}

\author{
Ana Laela Fatikhatul Choiriyah ${ }^{1}$ \\ ${ }^{1}$ Faculty of Law University of Jember, Jember, Indonesia \\ E-mail: analaela.fatikhatul99@gmail.com
}

\begin{abstract}
ABSTRAK
Perbankan syariah merupakan kegiatan usaha perekonomian yang diharapkan menjadi solusi alternatif bagi upaya optimalisasi potensi sumber daya ekonomi masyarakat, terutama bagi masyarakat muslim yang telah lama meragukan kehalalan sistem bunga dalam perbankan konvensional yang pada gilirannya dapat mengeliminasi segala bentuk praktik kegiatan usaha ekonomi ribawi. Secara yuridis formal, pengakuan terhadap prinsip ekonomi syariah telah dimasukkan ke dalam UU No. 3 Tahun 2006 tentang Perubahan atas UU No 7 Tahun 1989 tentang Pengadilan Agama menegaskan bahwa, pengadilan dalam tugas dan wewenangnya dapat memutuskan perkara Ekonomi Syariah, sedangkan persoalan penyelesaian sengketa ekonomi syariah relatif masih baru dan belum dikenal banyak dalam dunia hukum. Artikel ini bertujuan mengulas mengenai kesiapan hakim Pengadilan Agama dalam penyelesaian sengketa Ekonomi Syariah dengan menggunakan pendekatan yuridis-normatif, konseptual dan pendekatan undang-undang.
\end{abstract}

Kata Kunci: Sengketa, Ekonomi Syariah, Pengadilan Agama.

\begin{abstract}
Islamic banking is an economic business activity that is expected to be an alternative solution for efforts to optimize the potential of the community's economic resources, especially for Muslim communities who have long doubted the interest system in conventional banking, which can eliminate all forms of usury economic business practices, formally juridical recognition of economic principles. Sharia has been included in Law no. 3 of 2006 as an amendment to Law No. 7 of 1989, which confirms that the Court in its duties and authorities can decide Sharia Economic cases, while the issue of sharia economic disputes is relatively new and not widely known in the legal world. This article aims to to review the readiness of Religious Court judges in settlement of Sharia Economic disputes using a juridical-normative, conceptual and legal approach.
\end{abstract}

Keywords: Disputes, Sharia Economics, Religious Courts. 


\section{PENDAHULUAN}

Gagasan adanya lembaga Keuangan Syari'ah (LKS) yang berpotensi berdasarkan pada prinsip syariat Islam berkaitan erat dengan gagasan terbentuknya suatu sistem ekonomi Islam. Konsep ekonomi Islam secara Internasional muncul pada dasawarsa tahun 70an, ketika pertama kali diselenggarakan konferensi internasional tentang ekonomi Islam di Makkah pada tahun 1976. Di antara pemikirpemikir sistem ekonomi Islam tersebut terdapat pola kecenderungan yang berbeda-beda, pemikir yang cenderung kepada aspek teoretis, dengan memberikan alternative pada tataran konsep dan pemikir yang kecenderungannya pada aspek pragmatis yaitu dengan cara mendirikan lembaga-lembaga ekonomi dan keuangan yang beroperasi berdasarkan prinsip syari'ah, salah satu diantaranya adalah mendirikan lembagalembaga keuangan syariah.

Di dalam perkembangannya, kelompok pragmatis inilah justru lebih tampak keberhasilannya ketimbang pada aspek konsepsi, karena memang jauh sebelum adanya gagasan ekonomi Islam telah diawai dengan suatu upaya untuk mendirikan bank-bank Islam. Sehingga kemudian lembaga keuangan syari’ah yang lain pun bermunculan salah satunya dengan lahirnya Islamic development bank (IDB) pada tahun 1975 yang bertujuan untuk mendorong pertumbuhan ekonomi serta meningkatkan kesejahteraan sosial bagi Negara- negara anggota dan masyarakat muslim pada umumnya.

Pesatnya laju perkembangan lembaga keuangan syari'ah ini karena lembaga ini memiliki keistimewaan yaitu yang melekat pada konsep (buil in concept) dengan orientasi pada kebersamaan. Orientasi kebersamaan inilah yang menjadikan lembaga keuangan syari'ah mampu tampil sebagai alternatif pengganti sistem bunga yang selama ini hukumnya (halal atau haram). Namun demikian sebagai lembaga yang eksistensinya lebih baru daripada lembaga keuangan konvensional (Hasbi Hasan, 2010)

Penerapan Hukum Islam dalam kegiatan perbankan/ keuangan atau kegiatan ekonomi lainnya bukanlah pekerjaan yang sederhana. Dalam konteks seperti di atas, studi mengenai hukum Perbankan syariah atau hukum keuangan syariah menjadi suatu studi yang menarik dan menantang untuk dunia hukum di Indonesia dimana hukum positif (hukum yang berlaku) dinegara Indonesia berbeda dengan yang berlaku dengan hukum agama (Islam). Indonesia bukan negara Islam dan oleh karenanya pemberlakuan Hukum Islam tidak diberlakukan secara otomatis dalam kehidupan sosial kemasyarakatan kita. Pemberlakuan hukum agama (Islam) harus melalui proses yang disebut sebagai proses "positivisasi" hukum Islam. Dalam hal ini, hukum syariah diterima oleh negara dalam peraturan perundang- 
PENYELESAIAN SENGKETA PERBANKAN SYARIAH MELALUI PENGADILAN AGAMA; SUATU STUDI HUKUM NORMATIF Ana Laela Fatikhatul Choiriyah

undangan positif yang berlaku secara nasional. Oleh karena itu, bank syariah yang didirikan di negara yang sistem hukumnya dipinjam atau berasal dari hukum barat, seperti Indonesia, harus mengikuti tidak saja hukum syari'ah, tapi juga semua hukum nasional yang secara langsung atau tidak langsung mengatur bank syariah.

Aspek hukum Perbankan syariah, khususnya di Indonesia merupakan bidang yang baru dibidang ilmu hukum dan masih memiliki potensi yang sangat besar dalam pengembangan ilmu hukum dimasa mendatang. Interaksi yang intense antara hukum nasional dan Hukum Islam telah menjadikan bidang ilmu ini sangat menantang dari aspek hukum maupun dari aspek politik. Perkembangan dari peraturan perundang-undangan dan regulasi di bidang Perbankan dan keuangan syariah belum diikuti secara memadai oleh studi ilmu hukum. Interaksi antara hukum nasional dan Hukum Islam tersebut telah menjadikan bidang ilmu hukum ini menarik untuk didalami. Setelah sekian lama adanya dominasi hukum barat sebagai sumber-sumber hukum nasional kini kita ditantang untuk melihat Hukum Islam sebagai salah satu sumber hukum utama dalam menciptakan salah satu hukum yang sangat penting yaitu hukum perbankan dan keuangan syariah.
Jurnal Geuthèë: Penelitian Multidisiplin Vol. 04, No. 02, (Agustus, 2021), pp. 75-88.

\section{METODE PENELITIAN}

Penelitian ini menggunakan penelitian hukum normatif. Penelitian hukum normatif mencakup beberapa bagian, di antaranya: penelitian terhadap asas-asas hukum, sistematik hukum, taraf sinkronisasi hukum, perbandingan hukum dan sejarah hukum. Pendekatan yang digunakan dalam penelitian ini meliputi pendekatan konseptual, pendekatan perundang-undangan. Bahan hukum yang digunakan terdiri dari bahan hukum primer, sekunder dan non hukum. Bahan hukum primer terdiri atas UU No. 3 Tahun 2006 sebagai perubahan atas UU No 7 Tahun 1989 , UU No 21 Tahun 2008 dan Putusan Mahkamah Konstitusi Nomor 93/PUU-X/2012, Peraturan Mahkamah Agung Republik Indonesia Nomor 5 Tahun 2016, Peraturan Mahkamah Agung Republik Indonesia Nomor 14 Tahun 2016 Bahan hukum sekunder berupa buku, jurnal, dan karya tulis ilmiah hukum. Bahan non hukum berupa buku non hukum dan informasi yang diakses melalui internet.

\section{HASIL PENELITIAN DAN PEMBAHASAN}

1) Kesiapan Peradilan Agama dalam

\section{Penyeelsaian Sengketa Ekonomi Syariah}

Format hasil penelitian dan pembahasan tidak dipisahkan. Untuk naskah yang memiliki tabel, grafik atau gambar, dijelaskan sesuai kebutuhan, dengan keterangan gambar diletakkan di atasnya. 
PENYELESAIAN SENGKETA PERBANKAN SYARIAH MELALUI PENGADILAN AGAMA; SUATU STUDI HUKUM NORMATIF Ana Laela Fatikhatul Choiriyah

Pada prinsipnya penegakan hukum hanya dilakukan oleh kekuasaan kehakiman (yudisial power) yang secara konstitusional lazim disebut dengan badan yudikatif. Tinjauan pokok Undang-undang nomor 14 tahun 1970 Tentang Pokok-pokok kekuasaan kehakiman menyatakan hal sebagai berikut: (1)" Pengadilan tidak boleh menolak untuk memeriksa dan mengadili suatu perkara yang diajukan dengan dalih bahwa hukum tidak atau kurang jelas, melainkan wajib untuk memeriksa dan mengadili. Ketentuan pasal 14 ini dalam ilmu hukum dikenal dengan istilah ius curia novit artinya hakim dianggap tahu hukum. Sedangkan penjelasan pasal 14 berbunyi : (1) hakim sebagai orang pengadilan dianggap memahami hukum pencari keadilan yang datang padanya untuk memohon keadilan yang datang padanya untuk memohon keadilan. Menurut Bambang Hermanto (2014), keberadaan peradilan perdata bertujuan untuk menyelesaikan perkara yang timbul di antara anggota masyarakat perkara yang terjadi memiliki bentuk yang beragam, ada yang berkenaan dengan pengingkaran atau pemecahan perjanjian (breach of contract).

Pada masa reformasi, perubahan signifikan menyangkut kewenangan peradilan agama, secara konstitusional diperoleh melalui UU No. 3 Tahun 2006 sebagai perubahan atas UU No. 7 Tahun 1989. Pasal 2 Uu No. 3 tahun 2006 menegaskan" peradilan Agama adalah salah satu pelaku kekuasaan kehakiman bagi rakyat pencari keadilan yang beragama Islam
Jurnal Geuthèë: Penelitian Multidisiplin Vol. 04, No. 02, (Agustus, 2021), pp. 75-88.

mengenai perkara tertentu" pasal 49 menjelaskan kewenangan tersebut mencakup perkawinan, waris, wasiat, hibah wakaf, zakat infaq, shodaqoh dan ekonomi syariah. Dengan demikian titik penambahan kewenangan baru tersebut adalah zakat, infaq dan ekonomi syariah (Bambang Hermanto, 2014).

Kewenangan tersebut sejalan dengan perkembangan hukum dan kebutuhan hukum masyarakat khususnya masyarakat muslim. Eugien Ehrlich dalam Soerjono Soekanto (1985) menyatakan, hukum yang baik adalah hukum yang sesuai dengan hukum yang hidup di masyarakat". Ia juga menyatakan bahwa hukum positif hanya akan efektif apabila selaras dengan hukum yang hidup dalam masyarakat, dalam istilah antropologi dikenal sebagai pola-pola kebudayaan (culture pattern).

Keberadaan Peradilan Agama sebagai sebuah legal structure, berbanding lurus dengan kewenangan sebagai legal substance. sehingga jika structure-nya kuat tetapi legal substancenya tidak kuat. Hal ini seperti yang dijadikan alasan oleh anggota DPR ketika mengesahkan kewenangan ekonomi syariah dalam UU No. 3 Tahun 2006, dimana pertimbangan utamanya adalah bahwa ekonomi syariah adalah bidang perdata yang secara sosiologis merupakan kebutuhan umat Islam.

Kehadiran undang-undang nomor 3 tahun 2006 tentang peradilan agama pada mulanya telah menepis banyak anggapan sebelum disahkannya undang-undang nomor 21 tahun 
PENYELESAIAN SENGKETA PERBANKAN SYARIAH MELALUI PENGADILAN AGAMA; SUATU STUDI HUKUM NORMATIF Ana Laela Fatikhatul Choiriyah

2008 tentang perbankan syariah, dimana dalam rapat pembahasan RUU Bank Syariah di DPR, Pemerintah meminta agar sengketa bisnis bank syariah tidak ditangani oleh Peradilan Agama tetapi oleh peradilan umum. Alasannya penyelesaian sengketa bisnis syariah oleh peradilan agama dianggap tidak familier. Akan tetapi disisi lain , berdasarkan pasal 1851, 1855 dan 1858 KUH Perdata, penjelasan pasal 3 UU Nomor 14 tahun 1970 serta UU nomor 3 tahun 1999 tentang Arbitrase dan Alternatif penyelesaian sengketa, justru menunjukkan terbukanya kemungkinan para pihak menyelesaikan sengketa dengan menggunakan lembaga selain dari lembaga peradilan yang ada, seperti arbitrase dan perdamaian( islah).

Hal ini dapat dibenarkan oleh berbagai alasan karena Pengadilan yang selama ini dianggap sebagai the first and last resort dalam penyelesaian sengketa ternyata masih dipandang oleh sebagai kalangan hanya menghasilkan kesepakatan yang bersifat adversial, belum mampu merangkul kepentingan bersama, cenderung menimbulkan masalah baru, lambat dalam penyelesainya, membutuhkan biaya yang mahal, tidak responsif, menimbulkan antagonism diantara pihak yang bersengketa, serta banyak terjadi pelanggaran dalam pelaksanaannya. Bahkan dipandang kurang menguntungkan dalam dunia bisnis sehingga dibutuhkan institusi baru yang dipandang lebih efisien dan efektif.
Jurnal Geuthèë: Penelitian Multidisiplin Vol. 04, No. 02, (Agustus, 2021), pp. 75-88.

Dengan pertumbuhan Ekonomi Syariah yang menggembirakan di Indonesia menyebabkan Mahkamah Agung terus berinovasi dalam meningkatkan SDM para penegak hukum dibawah naungannya. Namun, adanya perbedaan tugas dan wewenang mengenai penyelesaian sengketa di dalam pasal Pasal 55 ayat (1) dan ayat (2) UU Perbankan Syariah menimbulkan kontradiktif.

Perbedaan tersebut menimbulkan ketidakpastian hukum bagi pemohon, seperti dijamin Pasal 28D ayat (1) UUD 1945. Pasal 55 UU perbankan syariah menyebutkan :(1) Penyelesaian sengketa Perbankan Syariah dilakukan oleh pengadilan dalam lingkungan Peradilan Agama. (2) Dalam hal para pihak telah memperjanjikan penyelesaian sengketa selain sebagaimana dimaksud pada ayat (1), penyelesaian sengketa dilakukan sesuai dengan isi Akad. (3) Penyelesaian sengketa sebagaimana dimaksud pada ayat (2) tidak boleh bertentangan dengan Prinsip Syariah.

Pasal 55 ayat (1) dan ayat (2)-nya dinilai kontradiktif karena ayat (1) secara tegas mengatur jika terjadi sengketa dalam praktik perbankan syariah harus merupakan kewenangan pengadilan agama. Sementara dalam ayat (2)-nya membuka ruang para pihak yang terikat akad untuk memilih peradilan mana pun jika terjadi sengketa praktik perbankan syariah. "Itu sangat jelas sekali, Pasal 55 ayat (2) tidak ada kepastian hukum yang bertentangan dengan Pasal 28D ayat (1) UUD 
PENYELESAIAN SENGKETA PERBANKAN SYARIAH MELALUI PENGADILAN AGAMA; SUATU STUDI HUKUM NORMATIF Ana Laela Fatikhatul Choiriyah

1945," tegasnya. Ketentuan Pasal 55 ayat (3) UU Perbankan Syariah tidak perlu ada apabila tidak ada ayat (2)-nya. Karena itu, agar mencerminkan adanya kepastian hukum, maka seharusnya Pasal 55 ayat (2) harus dinyatakan bertentangan dengan Pasal 28D ayat (1) UUD 1945 dan harus dinyatakan tidak mempunyai kekuatan hukum mengikat (hukum online, 2021).

Dengan adanya ketidakpastian mengenai penyelesaian sengketa ekonomi syariah tersebut Mahkamah Konstitusi mengeluarkan Putusan Mahkamah Konstitusi Nomor 93/PUU-X/2012 hal ini berawal dari seorang bernama Dadang Achmad (Direktur CV. Benua Enginering Consultant) mengajukan uji materiil pasal 55 ayat (2) dan (3) Undang-undang No. 21 Tahun 2008 tentang Perbankan Syariah terhadap pasal 28 ayat (1) Undang-Undang Dasar (UUD) 1945 yang didaftarkan di Kepaniteraan Mahkamah Konstitusi pada tanggal 19 Oktober 2012 berdasarkan Akta Penerimaan Berkas Permohonan Nomor322/PAN.MK/2012 dan telah dicatat dalam Buku Registrasi Perkara Konstitusi pada tanggal 24 September 2012 dengan No.93/PUU-X/2012.10 Persyaratan standing juga dapat dikatakan terpenuhi karena penggugat atau pemohon mempunyai kepentingan nyata dan secara hukum dilindungi.

Mengenai legal standing pemohon juga dinyatakan oleh Majelis Hakim Mahkamah Konstitusi bahwa pemohon adalah perseorangan warga negara Indonesia yang merupakan
Jurnal Geuthèë: Penelitian Multidisiplin Vol. 04, No. 02, (Agustus, 2021), pp. 75-88.

nasabah Bank Muamalat Cabang Bogor yang telah melakukan akad sebagaimana akta Notaris No. 34 tertanggal 9 Juli 2009 dan diperbaharui dengan akad pembiayaan Al-Musyarakah (tentang perpanjangan jangka waktu dan perubahan jaminan) dengan No. 14 tertanggal 8 Maret 2010 yang dibuat di hadapan Catur Virgo, SH. Notaris di Jakarta. Pemohon mengajukan dua orang ahli yang bernama Ija Suntana dan Dedi Ismatullah, dan telah didengar keterangannya di bawah sumpah dalam persidangan tanggal 20 Desember 2012 dan satu orang saksi bernama Muhammad Ikbal yang telah didengar keterangannya di bawah sumpah dalam persidangan tanggal 29 Januari 2013.

Terhadap pertimbangan hukum yang diberikan oleh Ahli dan Saksi dari Pemohon, Pemerintah, Dewan Perwakilan Rakyat (DPR), dan terakhir Ahli dari Mahkamah. Keterangan yang mendukung agar Mahkamah Konstitusi mengabulkan permohonan dari pemohon berasal dari pertimbangan hukum oleh Ahli dan Saksi dari Pemohon bersama Ahli dari Mahkamah. Sedangkan Pemerintah bersama DPR tidak mendukung hal tersebut karena menurut Pemerintah dan juga DPR ketentuan dalam penjelasan pasal 55 ayat (2) dan (3) Undang-undang Perbankan Syariah telah sesuai sepanjang tidak bertentangan

Dengan prinsip syariah sehingga dianggap telah memberikan kepastian hukum dan tidak bertentangan dengan pasal 28D ayat (1) UUD 1945. Namun Ahli dan Saksi dari Pemohon 
PENYELESAIAN SENGKETA PERBANKAN SYARIAH MELALUI PENGADILAN AGAMA; SUATU STUDI HUKUM NORMATIF Ana Laela Fatikhatul Choiriyah

bersama Ahli dari Mahkamah menganggap pada praktiknya tidak seperti itu, dengan dibukanya pilihan forum penyelesaian mulai dari pengadilan agama, basyarnas, hingga pengadilan negeri. Para pihak yang kalah bisa membawanya ke pengadilan lainnya sehingga sering kali terjadi timpang tindih kewenangan peradilan. Mahkamah Konstitusi menilai ketentuan Penjelasan Pasal 55 ayat (2) Undangundang Perbankan Syariah tidak memberi kepastian hukum.

Berdasarkan kenyataan yang demikian, walaupun Mahkamah tidak mengadili perkara konkret, telah cukup bukti bahwa ketentuan Penjelasan pasal 55 ayat (2) telah menimbulkan ketidakpastian hukum yang adil dan hilangnya hak konstitusional nasabah untuk mendapatkan kepastian hukum yang adil dalam penyelesaian sengketa perbankan syariah (Pasal 28D ayat (1) UUD 1945) yang bertentangan dengan prinsipprinsip konstitusi (Gala Perdana Putra Lubis). Terhadap penilaian, fakta dan hukum sebagaimana diuraikan di atas, Mahkamah Konstitusi menyatakan mengabulkan permohonan Pemohon untuk sebagian, yaitu Penjelasan Pasal 55 ayat (2) Undang-Undang Nomor 21 Tahun 2008 tentang Perbankan Syariah bertentangan dengan Undang-Undang Dasar Negara Republik Indonesia Tahun 1945 dan tidak mempunyai kekuatan hukum mengikat. Mahkamah Konstitusi juga memerintahkan pemuatan putusan ini dalam Berita Negara Republik Indonesia sebagaimana
Jurnal Geuthèë: Penelitian Multidisiplin Vol. 04, No. 02, (Agustus, 2021), pp. 75-88.

mestinya dan menolak permohonan Pemohon untuk selain dan selebihnya. Terhadap putusan Mahkamah ini, Hakim Konstitusi Hamdan Zoelva, Hakim Konstitusi Ahmad Fadlil Sumadi memiliki alasan berbeda (concurring opinion) dan Hakim Konstitusi Muhammad Alim memiliki pendapat berbeda (dissenting opinion).

Dengan adanya putusan Mahkamah Konstitusi tersebut Mahkamah Agung terus berusaha memperkaya SDM Hakim Pengadilan Agama terkhusus hakim Ekonomi Syariah dengan mengeluarkan Peraturan Mahkamah Agung Republik Indonesia Nomor 5 Tahun 2016 tentang Sertifikasi Hakim Ekonomi Syariah dimana dijelaskan dalam pasal 1 Sertifikasi Hakim Ekonomi Syariah adalah proses pemberian sertifikat hakim yang telah dinyatakan lulus seleksi administrasi, kompetensi, integritas dan pelatihan menjadi hakim ekonomi syariah. Hakim Ekonomi Syariah adalah hakim peradilan agama yang telah bersertifikat dan diangkat oleh Ketua Mahkamah Agung Republik Indonesia.

Perkara ekonomi syariah harus diadili oleh hakim ekonomi syariah yang bersertifikat dan diangkat oleh Ketua Mahkamah Agung Republik Indonesia. Yang bertujuan untuk Sertifikasi hakim ekonomi syariah bertujuan untuk meningkatkan efektivitas penanganan perkara-perkara ekonomi syariah di Pengadilan Agama/Mahkamah Syar'iyah sebagai bagian dari upaya penegakkan hukum ekonomi syariah yang memenuhi rasa keadilan. 
Sedangkan mengenai sertifikasi hakim ekonomi syariah sebagaimana dinyatakan Pasal 4 Peraturan Mahkamah Agung Republik Indonesia Nomor 5 Tahun 2016, meliputi: a. kewenangan hakim bersertifikat b. tahapan seleksi c. pelatihan; d. pengangkatan dan penempatan. pengawasan dan evaluatif, insentif dan disinsentif; dan g. pendanaan. Sedangkan perkara ekonomi syariah sebagaimana dimaksud pada Pasal 1 ayat (1) meliputi: a. bank syariah, b. lembaga keuangan mikro syariah, c. asuransi syariah, d. reasuransi syariah, e. reksadana syariah f. obligasi syariah dan surat berharga berjangka menengah syariah, g. sekuritas syariah, h. pembiayaan syariah, i. pegadaian syariah, j. dana pensiun lembaga keuangan syariah, dan k. bisnis syariah. Ketentuan sebagaimana dimaksud, termasuk tetapi tidak terbatas pada praktik transaksi lainnya yang berdasarkan pada prinsip syariah.

Selanjutnya, Pasal 8 Peraturan Mahkamah Agung Republik Indonesia Nomor 5 Tahun 2016 menyatakan, untuk dapat diangkat menjadi hakim ekonomi harus memenuhi kriteria sebagai berikut: a. persyaratan administrasi, b. persyaratan kompetensi, c. persyaratan integritas, d. mengikuti pelatihan; dan e. dinyatakan lulus oleh Tim Seleksi. Sedangkan mengenai kebutuhan hakim ekonomi syariah Mahkamah Agung menetapkan jumlah hakim ekonomi syariah sesuai dengan kebutuhan. Penetapan jumlah hakim sebagaimana dimaksud didasarkan analisis kebutuhan hakim ekonomi syariah oleh Mahkamah Agung Republik Indonesia.

Para hakim yang telah memenuhi persyaratan dan dinyatakan lulus oleh Tim Seleksi, akan mengikuti pelatihan selama dua belas hari dengan menggunakan kurikulum, materi ajar, serta metode yang disiapkan oleh Tim Khusus dan Pusdiklat Teknis Mahkamah Agung Republik Indonesia. Tim pengajarnya terdiri dari berbagai lembaga seperti: OJK, BI Akademisi dan praktisi yang kompeten. Saat ini MA telah melakukan kerjasama dengan berbagai lembaga seperti OJK dan BI dalam rangka meningkatkan kompetensi hakim ekonomi syariah. Para hakim yang telah lulus kemudian diangkat sebagai hakim ekonomi syariah oleh ketua Mahkamah Agung. Para hakim ini nantinya akan ditempatkan di pengadilan agama dan mempunyai kewenangan khusus menyelesaikan ekonomi syariah. Kinerja Hakim Ekonomi Syariah nantinya akan terus dievaluasi. Hal ini akan dijadikan sebagai dasar untuk menentapkan insentif ataupun disinsentif. Insentif yang diberikan dapat berupa pembiayaan seminar, pelatihan lanjutan ataupun pertemuan-pertemuan ekonomi syariah, baik untuk skala nasional maupun internasional. Sedangkan disinsentif dapat berupa pencabutan SK pengangkatan sebagai hakim ekonomi syariah.

Dengan adanya PERMA Sertifikasi Hakim Ekonomi Syariah tersebut, diharapkan penyelesaian sengketa ekonomi syariah bisa 
PENYELESAIAN SENGKETA PERBANKAN SYARIAH MELALUI PENGADILAN AGAMA; SUATU STUDI HUKUM NORMATIF Ana Laela Fatikhatul Choiriyah

diselesaikan oleh para hakim yang qualified dan teruji kemampuannya sehingga keraguan di kalangan pelaku industri ekonomi dan keuangan syariah menjadi sirna, berubah menjadi suatu kepercayaan (trust). Perlu diakui bahwa kepercayaan tidak akan muncul dengan seketika. Namun, dengan berjalannya waktu dan melalui proses dan usaha yang sungguhsungguh seperti dengan dikeluarkannya PERMA maka kepercayaan mulai dibangun oleh MA dengan sertifikasi hakim ekonomi syariah (business-law.binus.ac.id, 2016).

Dengan adanya sertifikasi syariah Mahkamah Agung juga mengeluarkan Peraturan Mahkamah Agung Republik Indonesia Nomor 14 Tahun 2016 Tentang Tata Cara Penyelesaian Perkara Ekonomi Syariah dimana dijelaskan bahwa Perkara ekonomi syariah dapat diajukan dalam bentuk gugatan sederhana atau gugatan dengan acara biasa. Sedangkan tata cara pemeriksaan dengan acara sederhana dijelaskan Gugatan dalam perkara ekonomi syariah dapat diajukan secara lisan atau tertulis dalam bentuk cetak atau pendaftaran perkara secara elektronik. Pemeriksaan perkara dengan acara sederhana adalah pemeriksaan terhadap perkara ekonomi syariah yang nilainya paling banyak Rp200.000.000,00 (dua ratus juta rupiah). Pemeriksaan perkara sebagaimana dimaksud mengacu pada Peraturan Mahkamah Agung Nomor 2 Tahun 2015 tentang Tata Cara Penyelesaian Gugatan Sederhana kecuali hal-hal
Jurnal Geuthèë: Penelitian Multidisiplin Vol. 04, No. 02, (Agustus, 2021), pp. 75-88.

yang diatur secara khusus dalam Peraturan Mahkamah Agung ini.

Sedangkan tata cara pemeriksaan perkara dengan acara biasa Pemeriksaan terhadap perkara ekonomi syariah dilakukan dengan berpedoman pada hukum acara yang berlaku kecuali yang telah diatur secara khusus dalam Peraturan Mahkamah Agung ini. Pemeriksaan terhadap perkara ekonomi syariah dapat dilakukan dengan bantuan teknologi informasi., Perkara ekonomi syariah harus sudah diputus berdasarkan tenggang waktu sebagaimana dimaksud pada Surat Edaran Mahkamah Agung Nomor 2 Tahun 2014 tentang Penyelesaian Perkara di Pengadilan Tingkat Pertama dan Tingkat Banding pada 4 (empat) Lingkungan Peradilan.

2) Penyelesaian Sengketa Keuangan Syariah Dengan Menggunakan Teori Hukum Progresif Satjipto Rahardjo

Format hasil penelitian dan pembahasan tidak dipisahkan. Untuk naskah yang memiliki tabel, grafik atau gambar, dijelaskan sesuai kebutuhan, dengan keterangan gambar diletakkan di atasnya.

Teori Progresif Satjipto Rahardjo, beliau yang mengonstruksikan masyarakat adalah tatanan normatif tercipta dari sebuah proses interaksi antar sosial dan kearifan nilai sosial. Ada sembilan teori hukum progresif yang beliau tawarkan (Nuhadi), yaitu:

a. Hukum pada dasarnya menolak tradisi analytical jurisprudence atau 
PENYELESAIAN SENGKETA PERBANKAN SYARIAH MELALUI PENGADILAN AGAMA; SUATU STUDI HUKUM NORMATIF

Ana Laela Fatikhatul Choiriyah

rechtsdogmatiek dan bermacam-macam pemahaman aliran misalnya legal realisme, freirechtslehre, sociological jurisprudence, interresenjuris-prudenz seperti di Jerman, teori hukum alam dan critical legal studies;

b. Hukum pada dasarnya menolak pemahaman bahwa ketertiban (order) hanya berlaku pada institusi kenegaraan dan kekuasaan;

c. Hukum progresif pada dasarnya ditujukan dalam melindungi rakyat menuju kepada keadilan ideal dalam hukum;

d. Hukum pada dasarnya menolak teknologi sebagai landasan teori hukum karena tidak bernurani;

e. Hukum pada dasarnya suatu institusi yang bertujuan mengantarkan manusia kepada kehidupan yang adil, sejahtera dan kebahagiaan;

f. Hukum progresif pada dasarnya hukum yang pro rakyat dan hukum yang pro keadilan;

g. Dasar asumsi dalam hukum progresif adalah hukum untuk manusia, untuk masyarakat yang lebih luas dan lebih besar. Jika ada masalah pelik dan besar, maka hukumlah yang ditinjau dan diperbaiki, bukan sebaliknya.

h. Hukum bukanlah suatu institusi yang bersifat absolut dan final melainkan
Jurnal Geuthèë: Penelitian Multidisiplin Vol. 04, No. 02, (Agustus, 2021), pp. 75-88.

selalu bergantung pada manusia melihat dan menggunakannya.

i. Hukum dalam prosesnya selalu berada di depan (Law as a process, Law in the making). Dalam hal ini cara berhukum secara progresif memerlukan empati dan keberanian. Cara berhukum secara progresif memberikan porsi yang cukup banyak untuk membuat kreativitaskreativitas baru yang tentunya berdasarkan atas keadilan dan kebutuhan masyarakat akan hukum tersebut.

Dari kesembilan konsep hukum progresif tersebut jika di lapangan para penegak hukum dapat menjalankan satu persatu maka di Indonesia dirasa dpat memenuhi rasa keadilan bagi para pencari keadilan, dimana para penegak hukum di dalam memutuskan dalam sebuah perkara akan melibatkan rasa empati, keberanian, nilai nilai dan isi muatan dalam Undangundang. Pendapat Noer Jameel, bahwa keadilan itu yang diciptakan bukan keadilan menurut teks undang-undang akan tetapi keadilan yang sebenarnya muncul dari tingkat kecerdasan serta kearifan berpikir penegak hukum dalam hal ini seorang hakim (Noor Jamel, 2014).

Berdasarkan 9 (Sembilan) konsep tersebut di atas, hukum progresif hendak mengembalikan hukum kepada jalur yang seharusnya (on the right track) dan untuk itulah Satjipto Rahardjo berpendapat 
PENYELESAIAN SENGKETA PERBANKAN SYARIAH MELALUI PENGADILAN AGAMA; SUATU STUDI HUKUM NORMATIF

Ana Laela Fatikhatul Choiriyah

diperlukan terobosan-terobosan hukum (legal breakthrough, bukan legal breaking) atau terobosan besar dalam proses pembentukan dan penegakan hukum. Dalam praktiknya, penerapan hukum progresif terdapat kelemahan. Para penegak hukum yang juga manusia dalam menerapkan hukum progresif telah banyak menimbulkan kerugian pula karena tidak ada kontrol atau pengendali yang dapat digunakan sebagai indikator atau pedoman (Noer Jameel, 2014).

Para penegak hukum dan aparat penegak hukum dalam praktiknya kemudian lepas kontrol dan menggunakan celah yang untuk memenangkan kemauan atau kehendaknya tanpa memperhatikan nurani. Contoh yang terjadi pada praktik penyelesaian sengketa perbankan syariah pasca berlakunya Undang-undang Nomor 21 Tahun 2008 (selanjutnya ditulis UU Perbankan Syariah). Pihak Bank Syariah dengan mendasarkan pada bagian penjelasan Pasal 55 UU Perbankan Syariah telah menetapkan secara sepihak tempat penyelesaian sengketa tanpa memperhatikan rasa keadilan, nilai rasa dan jiwa dari pihak nasabah bank syariah yang menginginkan penerapan prinsip syariah dalam melaksanakan transaksi ekonominya. Dalam hal ini pihak nasabah berkehendak agar tempat penyelesaian sengketa melalui Pengadilan Agama atau Basyarnas namun
Jurnal Geuthèë: Penelitian Multidisiplin Vol. 04, No. 02, (Agustus, 2021), pp. 75-88.

pihak bank syariah menghendaki tempat penyelesaian di Pengadilan Negeri.

Permasalahan yang terjadi dalam operasionalisasi bank syariah pada akhirnya mendorong masyarakat yang dirugikan melakukan judicial review atas UU Perbankan Syariah tersebut dan akhirnya pada tanggal 29 Agustus 2013 telah ada Keputusan Mahkamah Konstitusi Nomor 93/PUU-X/2012. Berdasarkan kasus dalam praktik perbankan syariah ini, tampak bahwa penyelesaian permasalahan hukum tidak cukup hanya diselesaikan dengan aturan semata, perlu upaya sinergisitas antara struktur penegak hukum dan lembaga hukumnya, substansi dan budaya hukumnya. Dalam hal ini penerapan budaya hukum tercermin dari penerapan nilai-nilai yang dikehendaki para pihak dalam hal ini Putusan Mahkaham Konsitusi memutuskan untuk menghapuskan bagian penjelasan Pasal 55 UU Perbankan Syariah demi keadilan dan penyelesaian berdasarkan interpretasi histori bahwa kompetensi penyelesaian sengketa hukum ekonomi syariah ada pada Pengadilan Agama.

Penerapan hukum progresif, belum dapat memberikan rasa keadilan bagi sebagian masyarakat karena dalam hukum progresif terdapat kelemahan yang tentunya harus dicarikan solusi dan penyempurnaan untuk perbaikan di masa yang akan datang. Dalam penerapannya, hukum progresif juga 
tetap berlandaskan pada hukum yang ada. Namun dalam hal ini hukum yang dimaknai secara luas. Bahkan memperhatikan nilainilai yang berkembang dalam masyarakat yang dapat digali pula dari nilai-nilai dalam sila-sila Pancasila. Dalam penerapannya juga diperlukan keberanian dan kecerdasan serta kearifan bagi pihak yang akan mengambil keputusannya dan menetapkannya (Dewi Nurul Mestjari, 2013).

Dalam penyelesaian sengketa perbankan syariah, yang digunakan bukan saja perjanjian (akad syariah) yang ada, namun politik hukum, sosiologi hukum, filsafat hukum bahkan psikologi hukum juga diterapkan dalam rangka memberikan jawaban atas permasalahan yang dihadapi masyarakat pemerhati dan peminat hukum ekonomi syariah. Turiman, berdasarkan konsep paradigma Pancasila bertawaf menjelaskan, bahwa Sila Ke satu menjadi nur cahaya yang menyinari keempat sila lainnya, yaitu Ketuhanan Yang Maha Esa, sebagai yang mewakili "God Spot" titik Tuhan/Kecerdasan Spiritual (Spiritual Quentient (SQ), menerangi Manusia yang berperikemanusiaan yang. Spiritual Quentient (SQ) merupakan kemampuan manusia dalam memahami arti (meaning) dan nilai (value) terbaik dalam kehidupan serta tujuan (vision) yang mendasar terhadap hal-hal dalam hidup dan kehidupan manusia sebagai khalifah di bumi. Spiritual Quentient (SQ) menjawab pertanyaan paling mendasar: "Siapa saya"?. "Untuk apa saya dilahirkan?" dan "Mau kemana saya setelah dilahirkan kedunia ini?" adil dan beradab sebagai yang mewakili kecerdasan pancaindra/Artificial Quentient (AQ). Bagi manusia-manusia yang menempati negara yang dinamakan negara kebangsaan Indonesia yang menjunjung persatuan, yaitu Persatuan Indone-sia, sebagai yang mewakili Kecerdasan Intelektual/Intelectual Quentient (IQ), dalam bingkai kerakyatan yang dipimpin oleh hikmat kebijaksanaan dalam permusyawaratan/ perwakilan sebagai yang mewakili kecerdasan emosional/ Emotional Quentient (EQ). Dalam mewujudkan keadilan sosial bagi seluruh rakyat Indonesia sebagai bentuk kecerdasan kreativitas atau Creativity Quentient (CQ), sehingga saat menterjemahkan isi yang ada dalam peraturan dan perundang-undangan yang ada dan tidak dibenarkan bertentangan dengan nilai-nilai Pancasila sebagai falsafah, nilai Ketuhanan dan keluhuran, kemanusian, persatuan, kerakyatan dan keadilan.

Berdasarkan Pasal 49 huruf (i) UU 3/2006 tentang kekuasaan kehakiman, maka penyelesaian sengketa keuangan syariah secara litigasi dilakukan oleh Pengadilan Agama. Adapun penyelesaian sengketa keuangan syariah secara non-litigasi dapat dilakukan melalui Arbitrase atau Alternatif 
PENYELESAIAN SENGKETA PERBANKAN SYARIAH MELALUI PENGADILAN AGAMA; SUATU STUDI HUKUM NORMATIF Ana Laela Fatikhatul Choiriyah

Penyelesaian Sengketa yang meliputi konsultasi, negosiasi, mediasi, konsiliasi atau penilaian ahli sebagaimana diatur UU 30/1999. Oleh karena keuangan syariah berjalan berdasarkan prinsip syariah, maka lembaga arbitrase yang digunakan adalah Badan Arbitrase Syariah Nasional (BASYARNAS). Dalam rangka mendukung penguatan kerangka hukum dalam pengembangan pasar modal syariah, perlu dibentuk satu regulasi khusus berupa undang - undang keuangan syariah yang di dalamnya mengatur secara komprehensif dari ketentuan umum hingga penyelesaian sengketa dengan memberikan kewenangan kepada Pengadilan Agama dalam penyelesaian sengketa secara litigasi. Dalam regulasi tersebut juga diatur mengenai penyelesaian sengketa keuangan syariah secara non-litigasi dengan memberikan kewenangan kepada Badan Arbitrase Syariah Nasional (BASYARNAS) sebagai lembaga penyelesai sengketanya. Dengan demikian, persoalan kekosongan hukum mengenai penyelesaian sengketa keuangan syariah mendapat kepastian hukum, inilah yang disebut dengan win-win solution, sebagai bentuk aplikasi solusi teori hukum progresif dalam menyelesaikan sengketa keuangan syariah.

\section{SIMPULAN}

Tugas dan wewenang Pengadilan Agama dijelaskan dalam Pasal 49 huruf (i)
UU 3/2006 tentang kekuasaan kehakiman, maka penyelesaian sengketa keuangan syariah secara litigasi dilakukan oleh Pengadilan Agama dimana dalam hal ini Mahkamah Agung terus berusaha memperbaiki SDM para hakim yang bertugas memeriksa dan memutus sengketa ekonomi syariah, dilihat dari keseriusan Mahkamah Agung dengan mengeluarkan Peraturan Mahkamah Agung Republik Indonesia Nomor 5 Tahun 2016 dan Peraturan Mahkamah Agung Republik Indonesia Nomor 14 Tahun 2016. Sementara, dalam penyelesaian sengketa ekonomi syariah berawal terdapat tumpang tindih antara undang-undang satu dengan peraturan undang-undang yang lainnya memunculkan dinamika konflik para pencari keadilan. Konflik tersebut berdampak pada adanya pihak yang merasa dirugikan dengan peraturan tentang tugas dan wewenang dalam penyelesaian sengketa ekonomi syariah. Namun dinamika yang berpotensi terjadinya konflik disahuti oleh Mahkamah Konstitusi dengan putusan Mahkamah Konstitusi Nomor 93/PUU-X/2012. Putusan ini menunjukkan Hakim Mahkamah Konstitusi berpikir hukum progresif dimana telah memberikan kejelasan terkait tugas dan wewenang penyelesaian perkara ekonomi syariah dengan bertujuan agar tidak terjadi kembali permasalahan yang sama dikemudian hari. Jika sudah terdapat kejelasan mengenai tugas wewenang 
PENYELESAIAN SENGKETA PERBANKAN SYARIAH MELALUI PENGADILAN AGAMA; SUATU STUDI HUKUM NORMATIF

Ana Laela Fatikhatul Choiriyah

penyelesaian sengketa ekonomi syariah meningkatkan SDM Hakim Ekonomi tersebut maka saat ini tugas Mahkamah Syariah.

Agung untuk terus berinovasi dan terus
Jurnal Geuthèë: Penelitian Multidisiplin Vol. 04, No. 02, (Agustus, 2021), pp. 75-88.

\section{DAFTAR PUSTAKA}

\section{BUKU}

Hasan, Hasbi, 2010, Kompetensi Peradilan Agama Dalam Penyelesaian Perkara Ekonomi Syariah:Gramatika, Jakarta.

Soekanto, Soerjono , 1985, Prespektif Teoritis Studi Hukum dalam Masyarakat: Rajawali, Jakarta. Hermanto, Bambang, 2014, Hukum Perbankan Syariah: Kuakaba, Yogyakarta.

\section{JURNAL}

Nuhadi, "Teori Hukum Progresif Dalam Menyelesaikan Sengketa Bisnis Keuangan Syariah", Jurnal Hukum Samudra Keadilan, Volume 14, Nomor 2, Juli-Desember.

Mustjari Dewi Nurul, 2013, "Penyelesaian Sengketa Ekonomi Syariah”, Vol. 20 No 2 Desember.

Gala Perdana Putra Lubis, "Analisis Putusan Mahkamah Konstitusi No.93/Puu-X/2012 Terhadap Penyelesaian Sengketa Perbankan Syariah Di Indonesia”.

Noer Jameel, 2014 ,"Hakim Progresif, Mengurai Benang Kusut Ketidak tertiban Masyarakat di Indonesia”, Academia.edu.

\section{INTERNET:}

https://www.hukumonline.comnasabah-bank-persoalkan-uu-perbankan-syariah.com di akses 09/06/2021, pukul 19: 03

https://business-law.binus.ac.id/2016/09/28/sertifikasi-hakim-ekonomi-syariah/ di akses tanggal 11 Juni 2021 Pukul 12:16

\section{PERATURAN PERUNDANG-UNDANGAN}

Undang-undang No. 3 Tahun 2006 tentang perubahan atas Undang-undang Nomor 7 Tahun 1989 tentang Pengadilan Agama.

Undang-Undang No 21 Tahun 2008 tentang Perbankan Syariah.

Peraturan Mahkamah Agung Republik Indonesia Nomor 5 Tahun 2016.

Peraturan Mahkamah Agung Republik Indonesia Nomor 14 Tahun 2016. 